\title{
Influence of Internet plus to International Business Development
}

\author{
Wei Xiong1, Zhen Zhao', Jingxuan Fang² \\ ${ }^{1}$ University of International Business and Economics, Beijing, China \\ ${ }^{2}$ Beijing 101 Middle School, Beijing, China \\ Email: profxiongwei@sina.com,drzhaozhen@sina.com,joannafjx@sina.com
}

Received 5 April 2016; accepted 23 April 2016; published 28 April 2016

Copyright (C) 2016 by authors and Scientific Research Publishing Inc.

This work is licensed under the Creative Commons Attribution International License (CC BY).

http://creativecommons.org/licenses/by/4.0/

c) (i) Open Access

\begin{abstract}
The paper compares the situations of world economy development in past 100 years briefly. With the rapid development of internet, the paper distinguishes the traditional business model from future business model development. As an important tool of international business, internet is becoming a leading role in both business increasing and marketing developing with its users fast growing. With internet plus time coming, international business will be related to internet tightly in current time and future based on internet characteristics.
\end{abstract}

\section{Keywords}

Influence, Internet, Economy Development, Marketing, GDP

\section{Introduction}

Internet first appeared in 60 to 70s of last century. In 1985, National Science Foundation (NSF) of USA created NSFnet among universities. It was an important step for internet development. After that in 1994 to 1995 , NSFnet was changed to be used as business objective [1]. Internet affected our world a lot gradually from then on. Internet is a milestone to the world and international business. With the internet growing rapidly and deeply, many changes happen in various aspects especially in business. The relevant analysis could be done briefly.

\section{Glance about World Economy from the Beginning of Last Century}

In order to understand world economy in history, world GDP situation and population in the world could be as important parameters to show easily.

Looking back to recent over 100-year history, GDP number in the world changed greatly in different population period. According to IMF relevant announced data, world GDP and population relation could be showed as 
Table 1 [2]. In first 50 years, though world GDP increased 12 times, the number value was only 1054 billion USD in 1950. However, in the following second 50 years, world GDP increased very fast and arrived at 31075 billion USD in 1999 which was almost 30 times comparing to the number of 1950. Now world GDP has hit 82,000 billion USD. During the relevant period, the population growth speed was obviously slower than GDP. The data shows that definitely there is something to help world economy develop more rapid and more efficient in recent several decades.

\section{Internet Changes Traditional Marketing Model in Business and Economy Radically}

Through above brief analysis, a question appears naturally. Why world economy grows so fast especially in past 50 years? What kind of things happened or changed in business related with the coming of internet?

Concretely speaking, economy or business growing has tight relationship with marketing and business tools. The key point of marketing to business development is making use of the speed of wideness of technique to access customers. From the brief review of marketing history, the rapid growth of internet to the importance of marketing and business can be recognized easily.

\subsection{Brief Review about Business Development Steps Relevant to Marketing}

The concept of marketing can be traced back to very old times. From then the road of marketing on business development can be clarified as below several steps.

\subsubsection{Handicraft Is the Initial Marketing}

At very old times, people need to do buying and selling necessary goods in daily life. In order to clarify the difference, the workers created some signals to make the difference on their products. This is the initial marketing and brand. Obviously business development is not easy.

\subsubsection{Printing Machine Lead to Paper Information}

At the middle of $15^{\text {th }}$ century, printing machine appeared. Information can be spread through published papers. This is a very great development to marketing and business development. However, transportation speed limited the information spread.

\subsubsection{Railway and Telegraph}

Although information can be printed, till roughly 150 years ago, buying and selling behavior only was below people walking or horse-riding limit. This decided the marketing spreading scope. With the railway and telegraph, business development and marketing faced a huge jump. Because people could easily buy and sell through the transportation tools development even if the distance is over $1000 \mathrm{~km}$. Telegraph could let marketing information arrive destination ahead of people. Business customers and potential leads increased very much. Thus business development is easier.

Table 1. World GDP and population relation in world economy development history.

\begin{tabular}{cccc}
\hline Time & GDP (Billion \$USD) & Population (Billion) & Time of Time Growth (GDP/Population) \\
\hline 1900 & 80 & 1.65 & - \\
1950 & 1054.8 & 2.55 & $1200 \% / 54 \%$ \\
1960 & 1367 & 3 & $29.6 \% / 17.6 \%$ \\
1974 & 5716.5 & 4 & $318.2 \% / 33.3 \%$ \\
1987 & $17,547.5$ & 5 & $207 \% / 25 \%$ \\
1999 & $31,075.4$ & 6 & $77.1 \% / 20 \%$ \\
2012 & 71,700 & 7 & $130.7 \% / 16.7 \%$ \\
2015 & 77,300 & 7.32 & $7.81 \% / 4.57 \%$ \\
\hline
\end{tabular}




\subsubsection{Telephone and Automobile Lead to Mass Marketing}

Roughly one century ago, automobile appeared. With telephone technique break-though, a new marketing automobile combining with telephone happened. The method had been used today. Then besides newspaper and magazine, broadcast became as a new marketing and business development way happening. Thus more customers touching and the concept of mass marketing emerged.

\subsubsection{Retail Business Marketing Tools}

With more and more make-up such as post, telephone, railway and automobile etc, retail business men used mail-order list way to promote products. It became one of most effective and legendary tools. After that with TV appeared, the golden time of marketing was coming. In the past half century, through TV, product list, voice based on wireless and creative advertisement combining together, more and more potential customers and business leads could be reached and got. So business development is blooming.

\subsection{Internet Bring More Opportunities and Play Important Part in Business Development}

The basic internet structure appeared on roughly 50 years ago, it gave us a business platform. On this platform, we could play game, go shopping, watch TV, make friends and do research etc. With internet, we have to do many reforms [3].

In the past 10 to 20 years, internet as a new media which reflected very quickly and penetrated strongly leaded to bombed growth on marketing directly. Almost everyone who has PC could set up web station and promote brand. The relevant investment is almost zero. The game rule had been totally changed [4]. Now with the mobile phone widely used, mobile internet is developing rapidly.

Internet is becoming a marketing and business tool at our new time. It has brought us an unimaginable huge reform. In human history progressing, when the communication speed and wideness had tremendous and revolutionary progress, it would lead to a new height of marketing and business development. Internet time has surpassed any times of history. There is nothing like internet speed and wideness which could make us dizzy. And internet can be instant and global [5].

It is because internet almost could touch everyone and everywhere, our life and future will be affected greatly. Not only to our individual but also to our organization, environment, family and business etc internet will bring us many things very much. Comparing to traditional marketing model, internet affects a lot in business and economy radically.

\section{Internet Contribute a Lot to General Business Model}

With the internet huge and rapid growth today, to some extent, the customers relevant to internet represent business new growth and development especially in international business. The vendors or business sellers who get advantages on internet business model will win easily in business competition. So internet should be focused in future business.

\subsection{General Business Model Pattern}

Brad Sugars in his Instant Leads summarizes the general business model pattern. It is shown as Figure 1.

The relevant explanation to general business model is shown as below [6].

\subsubsection{The Parameters to Describe General Business Model}

More customers, more revenues and more profits are parameters to measure business commonly in our society today. However, if we analyze from Figure 1 carefully, it is easy to find that these key parameters-customers, revenue and profit do not exist in isolation. These parameters are only results that those factors affect them.

\subsubsection{The Factors to Affect General Business Model Result}

Figure 1 has showed some factors effect to us. If we want to get more customers in business, we should increase both business leads and conversion rate. More leads, more potential customers and prospects in business. Conversion rate reflects the capability that we transfer potential business customers to definite purchasing customers. And the final number of customer is decided by both leads and conversion rate. 


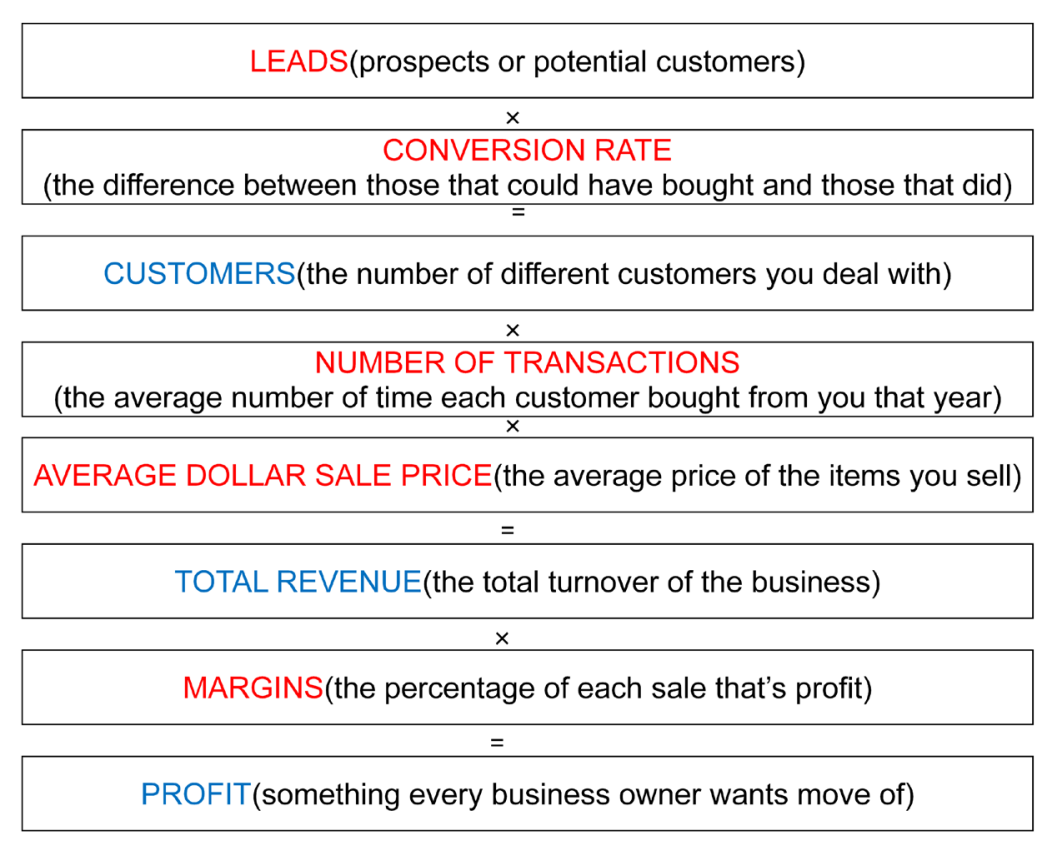

Figure 1. General business model pattern.

The revenue amount is relevant to purchasing customers. However, the turnover will be affected by each customer purchasing times in a period like a year and each time purchasing price. So the total revenue will be based on customer number and will be affected by number of transactions and selling price.

To the profit, it is easily understood that the profit will be decided by margin percentage.

So we can easily find though business results could be described by customers, revenue and profit, the root factors include leads, conversion rate, number of transactions, average selling price and margin actually.

\subsection{Internet Is Playing Very Important Part in Business Development}

Today internet plus has become a trend globally. With internet development and high technique progress, more and more new application will be installed. Currently internet user number is still growing rapidly worldwide. With internet wide application in business and among people, internet is both affecting our business greatly and changing the weight portion in our business. Business is no longer local, regional but international. This kind of international business has its own characteristics. And successful business development will be connected with the sustained influence trend of internet in the future.

\subsubsection{Fast Growing on Internet Users Leads to More Business Potential and Development}

At the end of 2015, global internet users surpassed 3.2 billion. And the trend is displaying growth ongoing as Figure 2 showed [7]-[10].

It is showed that internet is widely used in worldwide. In 2010, worldwide internet penetration rate is $29 \%$. In 2015, the number grows to $44 \%$. With the fast growing of both internet access and users number, it is easily to enlarge leads to various kinds business and strengthen the potential customer base in general business model. Based on it, successful business development could be expected. And it will affect world economy and international business development further.

According to the announced data of eMarketer, worldwide e-commerce revenue growth trend displays as Figure 3 [11].

During 2010 to 2015 period, global e-commerce business growed nearly 2 times. And the number will go on growing. Based on eMarketer forecast, e-commerce global revenue will touch 3500 billion USD in 2019. And the ration of this kind of international business through internet which occupizes ration of worldwide grand total retail business revenue will increase from 7.3\% in 2015 to $12.4 \%$ in 2019. So with the internet plus time coming and developing, the relevant issues of this kind of international business should be analyzed in detail. 


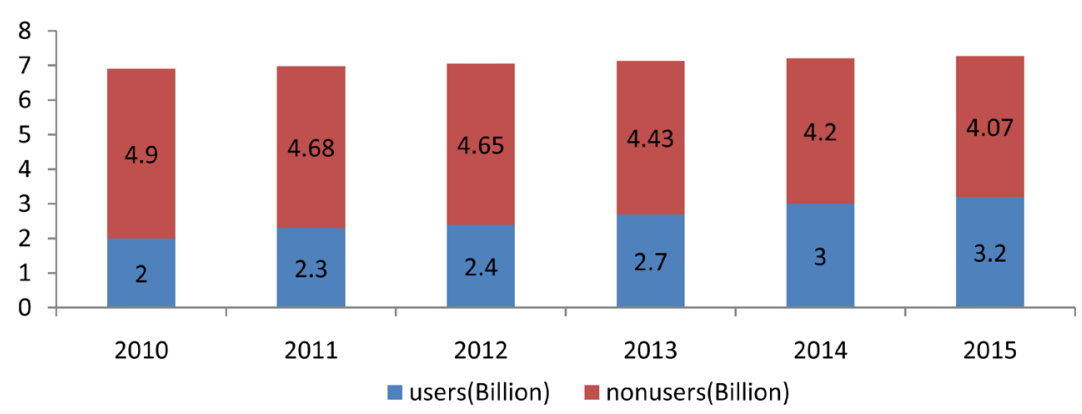

Figure 2. Global internet users’ situation.

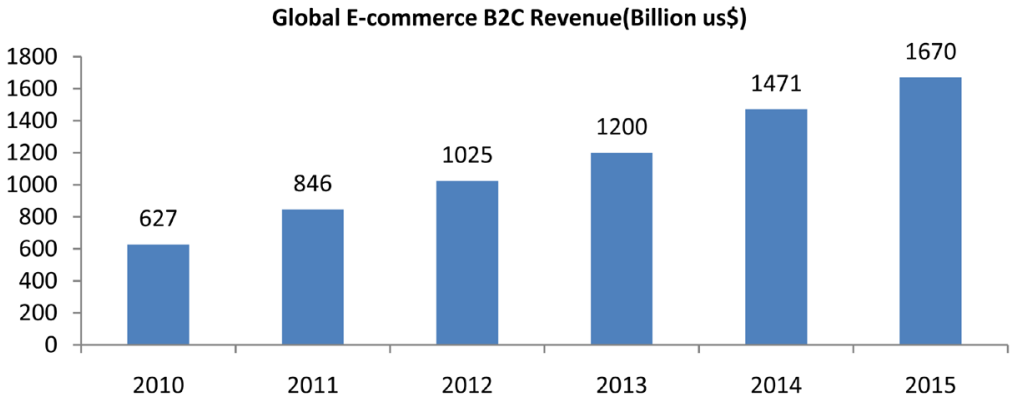

Figure 3. Worldwide e-commerce revenue.

\subsubsection{Internet Also Affects Other Factors of General Business Model}

According to ITU announced data, global mobile users' situation is showed in Figure 4 [12] [13].

In 2015 global mobile number had hit the number of world population. 2 billion of them used mobile internet. This is a great platform for both marketing development and business growth. Because these users could be touched anywhere easily.

With the internet leads base increase, marketing and promotion tools could be implemented. Since marketing tools can be easily and efficiently used through internet, it will be good to the conversion rate improvement in general business model.

Comparing to traditional selling tools, internet now becomes a simple and comfortable platform to do business and marketing promotion. Product introduction and promotion could be showed perfectly through internet and computer or mobile screen. Customers needn't arrive at the exchanging site. Depending on computer or mobile network, customers almost could exchange at home, office and everywhere. Since it is very convenient, the number of transactions could be improved easily in general business model. Because of the same reason, with the exchanging and marketing expense decrease, it will also be good to improve average selling price.

Because of the internet being used, whether buyers or sellers could save much cost on physical store, employee and rent for the house etc. This definitely could lead to the margin improvement in general business model. So the internet plays a very important part in successful business development.

\section{World Economy and International Business Will Be Influenced Deeply by Internet plus}

In internet plus time, with the development of internet, internet of things (IOT), mobile internet, big data and cloud calculation technology etc., e-commerce grows very rapidly. According to United Nations Conference on Trade and Development (UNCTAD) forecast, international business focused on e-commerce occupies $30 \%$ to $40 \%$ global trade revenue. In future, the number will continue to grow.

\subsection{Advantage of International Business Based on Internet}

The cause of rapid development of international business based on e-commerce is related to the unique advantage of its business model. 


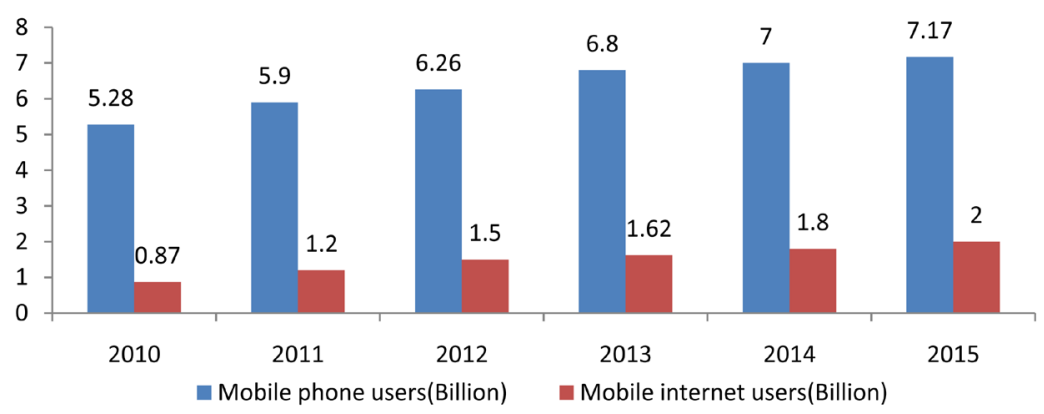

Figure 4. Global mobile users' situation.

\subsubsection{International Business Based on Internet Is the Newest Development \\ Trend of International Trade}

After financial crisis of 2008 the income of consumers grew very slowly. More and more consumers began to choose purchasing foreign products with high performance and low price through internet directly. In order to avoid risk, more and more import resellers selected to decrease big order instead of small order. Long term purchasing was changed to short term business. And deal amount dropped obviously. Traditional big amount business was changed to small amount, more deals and fragment business.

\subsubsection{Price Could Be Cut Effectively}

The product selling road of international business based on internet only includes factory, online platform and overseas trader. Then product arrives at consumer easily. The gross margin and net margin can be several times of traditional business model. In future the sell-through road could be simplified further. The product could be designed and produced based on the requirement of customer. This kind of C2B model will lead to the product direct delivery to overseas consumer through online platform. The original cost could change to the part profit of manufacturer and commission of e-commerce platform. And remained part could become the discount of consumer.

\subsubsection{Upstream and Downstream Partners Belong to Modern Service Industry}

International business based on internet needs many relevant partners including logistics, electronic payment, electronic authentication, IT service, network sales and marketing and etc. These parts all belong to modern service industry. Even to traditional express delivery and logistics delivery, the IT system will be needed. The relevant goods will not only have two-dimensional code and bar code but also could be queried and tracked on e-commerce platform. All payment could be finished through net bank or third party payment platform.

\subsubsection{Consumer Driven}

International business based on internet mainly satisfies the need of consumers who could not purchase relevant product in their country. The part is an additional incremental quantity to trade. International e-commerce platform could display the same type products worldwide. Performance to price will be important factor to consumer to make decision on purchasing or not. This is a consumer driven business. Consumers have more rights to select without limitation of region. And it will be the trend of development of international business based on internet.

\subsection{Huge Change at Internet plus Time in International Business}

Internet has created a different environment for the marketing and business or economy. Internet has changed the past role of strategy and competition. Undoubtedly, profitability has decreased in different industries by appearance of internet whether in domestic business or international business. With current big data, cloud calculation and the combination with internet application, more and more global internet companies appear. Wherever internet growing faster, the companies bigger. For instance, China has contributed four among the World's Top 10 Internet companies. In addition, the combination of internet and many traditional industries like finance, transportation, and service industries such as food \& beverage has enabled smoother communication, better experiences and rating systems for these industries and services [14]. 


\subsubsection{Retail}

Through business model like C2C and B2C, the price of goods is very transparent. The cost of information got to end users could be decreased greatly. This leads to the real price range being got to everyone. The information of asymmetry like William Poundstone described in his priceless is difficult to appear in internet plus time [15]. Thus price will be synchronous through combination of online and offline. The product which has outstanding end user experience will take the cake.

For example, customer relationship management or CRM is widely used in business management. In general business model, 1 to 1 management method could be used and try best to meet customer need [16]. However, with huge number of customers and different needs at internet plus time, it is really a problem to be solved. Recently the CRM solution based on sales cloud of salesforce.com had made great progress in this area. Over 100,000 enterprises select this CRM solution to manage their customers and business development so as to supply personal service.

Similarly WeChat e-commerce could also use this model. In China there are 400 to 500 million WeChat active users monthly [17]. The market is quite big and ongoing internationally.

\subsubsection{Wholesale}

Traditional wholesale business is usually limited by region. The resellers need to take the risk every time. With Alibaba B2B model appeared, the risk dropped to the lowest extent. Under the internet plus influence, B2B will be globalized totally. The trust issue in the past will be set up very well with time going. With internet growing to some extent, the resellers will disappear gradually. More and more business is going to change to B2C model.

\subsubsection{Manufacturing}

The traditional manufacturing is not open. The manufacturer decided what kind of product being made. However, with the internet application, the customers have opportunity to participate in the loop of production. The product could be made as they want. The relevant business model is customer to business (C2B). As Kevin Kelly described in the technium, internet time will create huge strength [18]. The big scale advertisement and production time will be ended. Everyone will be designer, producer and decision maker.

\subsubsection{Advertisement}

Advertisement has entered accurate delivery time. In international business, consumers could be delivered information of product locally if they search with correct and valuable information. For example, in China, if anybody searches relevant key word of product on Baidu, Google or Taobao, the relevant product advertisement searched will appear when related alliance network station being entered.

In general business model, MBO or management by objective method is often used. When setting up business objective, SMART method is often used. The objective is specific, measurable, achievable, relevant and time setting [19]. But based on the characteristics of internet, business management whatever selling process, marketing, product, SCM and service etc should be improved. Now with the Cloud technology application, more and more vendors and business partners use the relevant solution from like IBM which is cloud platform customers service solution supplier to analyze customers' activities and intents in digital. For example, through internet data, the customer habit and intent could be recognized and analyzed. Through internet, the relevant ads and marketing tools could be displayed to special customer. And the willing to purchase could be improved through this kind of special information delivered. Thus the customers could be served more efficiently and effectively. It will lead to better business result directly.

\subsubsection{Telecommunication}

With internet development, the link among people is very tight. Now people less and less rely on telephone and message. WiFi will be everywhere. People will enter internet of things (IOT) time. Telecom is not only among people but also between people and things, things and people and things and things. Now with light fidelity ( $\mathrm{Li}$-Fi) technique becoming mature, the telecommunication will be 100 times upgraded. Through mobile internet, WeChat and etc these kinds of tools people could communicate with each other easily.

\subsubsection{Logistics}

In international business with internet, high quality of logistics including capability, responsibility and etc. are 
required. Process of logistics will be enhanced very much under cruel competition. In future, only with high quality and fast delivery capability companies like Amazon, E-bay, Fedex, JD, SF could survive very well.

\subsubsection{Finance}

Internet finance is a new kind of model based on payment, cloud calculation, social internet \& search engine and APP etc internet tools. It is a kind of inclusive financial system. Comparing to traditional finance, it has many characteristics like strong transparency, high participation, good cooperation, low cost and easy operation etc. Unlike traditional business model displaying that $80 \%$ performance come from $20 \%$ products, long tail model can be explained to it. Only if both storage and channel are big enough, the pile-up of small \& tiny market could compete with main market. In fact long tail model needs two preconditions. One is low cost enough. The other is enough customers. The profit could be made easily because of two factors.

Third-Party Payment developed very fast in international business. The business is based on big data information processing. And foundation is cloud calculation. With the relevant tools utilized, the international business through internet could be run easily.

\subsection{Several Things Need to Be Solved through Internet to Successful International Business}

International business is growing rapidly because of internet penetration growth especially with mobile internet application. However, several things need to be solved very well so as to get long term sustained development.

\subsubsection{Supervision}

From the analysis above, safe payment is very important in international business with internet whether retail or wholesale. Now there are many methods on payment. On B2B model, payment is usually finished by credit card and bank transfer. On B2C model, $3^{\text {rd }}$ party payment is widely used like PayPal with 132 million users and 25 kinds of money supported. From supervision angle, $3^{\text {rd }}$ party payment is not clarified whether domestically or internationally both in USA and EU. In the USA, $3^{\text {rd }}$ party payment is supervised through authorized certification, course of dealing, two layer supervision, dedicated department and law support etc. In EU, $3^{\text {rd }}$ party payment is supervised through initial capital limit, investment activity limit and risk reserve etc.

However, the risk of supervision is actually low in developed countries and region of the world. Because development of internet and international business is very stable and supervision is often mature. The key point of supervision should be in developing countries and region of the world. For example, China has become the largest market of B2C with e-commerce and international business with internet. Recently some P2P business appeared cheating business. On supervision road, China has a long distance to go.

\subsubsection{Credit}

Credit should become the foundation of international business with internet. In USA and EU, almost everyone has sole credit code with whole life. Credit becomes most important thing to everyone. If credit record has problem, the relevant people is difficult to survive. However, in developing countries and region of the world, though the international business with internet is growing fast there are many issues on credit. For instance, in China, on 2015 November $11^{\text {th }}$ Alibaba got nearly 100 billion RMB order but actual delivery was just 50\%-60\%. And many deals were criticized with low quality products even counterfeit. The following issues like returned products freight, complaints even legal action happened. If everyone has credit thinking and cherish credit, many issues could be avoided. And the international business with internet could be run easily.

\subsubsection{Custom and Logistics}

In USA and EU, tax of goods of e-commerce internationally is zero or very low. This kind of business is protected in developed countries. So the customs inspection is simple. However, because of different price strategy of product in different region of the world grey import goods maybe appear. In order to avoid original batch high value goods with taxation being changed to single low value duty free goods, some rules should be set up. These rules can regulate goods volume, individual logistics, packing list and invoice and etc so as to avoid to heavy domestic market impact. 


\subsection{Some Points on Internet plus Need to Be Recognized}

\subsubsection{Cost Is Key Point of Internet plus Related Industries}

In the mobile internet era, new customers, new market and new value could be created through internet plus new channels, new ways and new applications. However, the relevant management key point is cost. Free is only one marketing way in a short time. For a long term, free would be an issue to any vendors.

\subsubsection{Internet Plus Is Not Everything}

Internet has many advantages including good interface, near customers need, fast upgrade speed, precise marketing, quick response to customer, low cost, online service, etc. However, internet could not replace product innovation, technique research and development, product production and supply chain management, etc. Internet finance also could not change the core issue risk control [20]. So internet is not everything. Internet is only one of tools to improve marketing, international business and economy.

\section{Summary}

In conclusion, internet is changing our world a lot. The most valuable point of internet is not that internet creates a lot of new things. The key point is through internet people could dig all current industries again. Based on the transparent information shared and the big data integrated, the relevant resources could be utilized to the maximum extent. Internet plus time will play very important part in successful sustained international business development.

\section{References}

[1] Po, Y.M. (2014) Internet Origin and Development. Inter-Commerce Group.

[2] International Monetary Fund (2016) World Economy Prospect.

[3] Cunningham, M.J. (2002) E-Business. Capstone Publishing, London.

[4] Mariotti, J. (2003) Brands and Branding. Shanghai Far-East Press, Shanghai.

[5] Mariotti, J. (2002) Marketing. Shanghai Far-East Press, Shanghai.

[6] Sugars, B. (2006) Instant Leads. McGraw Hill, Inc, New York.

[7] Facebook (2015) State of Connectivity Report.

[8] International Telecommunication Union (2015) Global Internet Application Report.

[9] International Telecommunication Union (2014) 2014 Information and Telecom Technique Report.

[10] eMarketer (2014) 2013-2018 Internet Users Forecast Report.

[11] eMarketer (2014) 2014 Global e-Commerce Report.

[12] International Telecommunication Union (2015) Annual Internet Survey Report.

[13] International Telecommunication Union (2013) World Report.

[14] Feng, Z. (2015) Creating Value by Connecting People. The LINK, 4, 58-61.

[15] Poundstone, W. (2011) Priceless. Sino-Culture Press, Beijing.

[16] Jay, R. (2003) Customers. Shanghai Far-East Press, Shanghai.

[17] Chen, K.G. (2014) Worry of WeChat E-Commerce: O2O or Platform. IT Time Weekly, 19, 37-38.

[18] Kelly, K. (2012) The Technium. Electronic Industry Press, Beijing.

[19] Tang, G.L., Gao, C. and Lu, C. (2010) CEO Planning and Budget System. Peking University Press, Beijing.

[20] Yang, Y.Q. (2014) Both Internet and Honesty Could Become Increase Engine of Enterprise. IT Time Weekly, 17, 13. 